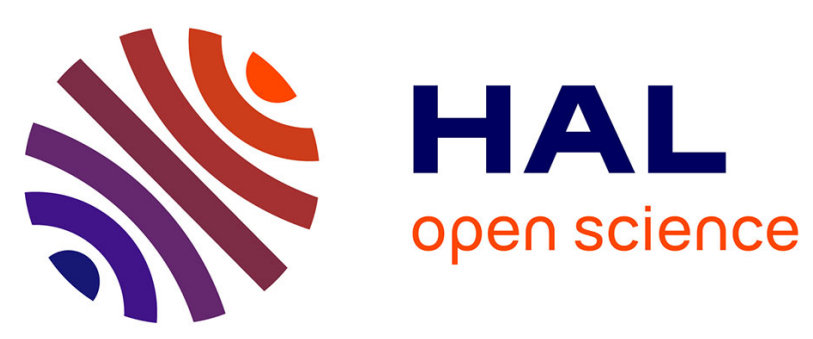

\title{
Response to comment on "The interaction of cells and bacteria with surfaces structures at the nanoscale"
}

K. Anselme, P. Davidson, A.M. Popa, M. Giazzon, M. Liley, Lydie Ploux

\section{To cite this version:}

K. Anselme, P. Davidson, A.M. Popa, M. Giazzon, M. Liley, et al.. Response to comment on "The interaction of cells and bacteria with surfaces structures at the nanoscale". Acta Biomaterialia, 2011, 7 (4), pp.1936-1937. 10.1016/j.actbio.2010.12.002 . hal-02384191

\section{HAL Id: hal-02384191 \\ https://hal.science/hal-02384191}

Submitted on 2 Dec 2020

HAL is a multi-disciplinary open access archive for the deposit and dissemination of scientific research documents, whether they are published or not. The documents may come from teaching and research institutions in France or abroad, or from public or private research centers.
L'archive ouverte pluridisciplinaire HAL, est destinée au dépôt et à la diffusion de documents scientifiques de niveau recherche, publiés ou non, émanant des établissements d'enseignement et de recherche français ou étrangers, des laboratoires publics ou privés. 


\title{
Response to comment on « The interaction of cells and bacteria with surfaces structures at the nanoscale."
}

\author{
K. Anselme ${ }^{1 *}$, P. Davidson ${ }^{1}$, A.M. Popa ${ }^{2,3}$, M. Giazzon ${ }^{3}$, M. Liley ${ }^{3}$, L. Ploux ${ }^{1 \S}$
}

${ }^{1}$ Institut de Science des Matériaux de Mulhouse (IS2M), CNRS LRC7228, Université de Haute-Alsace, Mulhouse, France

${ }^{2}$ Abteilung Schutz und Physiologie, EMPA, St. Gallen, Switzerland

${ }^{3}$ Centre Suisse d'Électronique et Microtechnique (CSEM), Neuchâtel, Switzerland

For further information, please mail to :

*Karine Anselme

Mailing address: IS2M, 15 rue Jean Starcky, BP2488, 68057 Mulhouse cedex, France

Phone number: +33389608766

Fax number: +33389608799

Email address: karine.anselme@uha.fr

${ }^{\S}$ Lydie Ploux

Mailing address: IS2M, 15 rue Jean Starcky, BP2488, 68057 Mulhouse cedex, France Phone number: +33389608798

Fax number: +33389608799

Email address: 1ydie.ploux@uha.fr 
In agreement with Dr. Schilardi and collaborators, the authors are also convinced that bacteria are far from simple colloidal particles and that they are able to sense topographical features of the surface and to react accordingly, which nevertheless has not been strictly demonstrated so far. However, it cannot be expected that bacteria are completely protected from processes affecting colloidal particles, especially from dewetting processes [1]. The author's conviction is that the experiments conducted by Dr. Schilardi and coll. in their recent article [2] were affected by dewetting-related experimental artifacts. In particular, bacteria localization may have been modified by air or nitrogen drying, even in a relative humidity greater than $70 \%$ or when the sample was kept in air during a short time before immersing it again (conditions used by Schilardi and coll. for AFM imaging and for the washing procedure prior to epifluorescence imaging, respectively). A dewetting process occurs whatever the humidity of the surrounding air environment $[3,4]$. It is due to the liquid evaporation, leads to meniscus formation, convective flow, rupturing, dewetting, and capillary-bridge formation. As soon as environmental conditions allow evaporation of the colloidal suspension, colloidal particles are driven by the threephase contact lines, which will lead to their organization $[5,6]$. Bacteria are unlikely to be able to resist to these driving forces. Our review (figure 9) [7] displays an example of such colloidal-like behavior of bacteria. Another example, leading also to bacteria organization and alignment with grooves, is given in Figure 1. Bacteria orientated much more with grooves when colonized substrate was dried before to be immersed again in liquid. Despite the longer time the substrate stayed in air in our experiment compared to those of Dr. Schilardi and coll., this demonstrates that dewetting processes can affect bacteria organization. Finally, it can be asserted that experimental dewetting-related artifacts play a role in the results of studies addressing bacteria organization to surface, as soon as an interface between the substrate and air is created before observation. Therefore, the conclusion made by Dr. Schilardi and her group in the article [2] should be rather considered as a hypothesis that still needs to be demonstrated. 

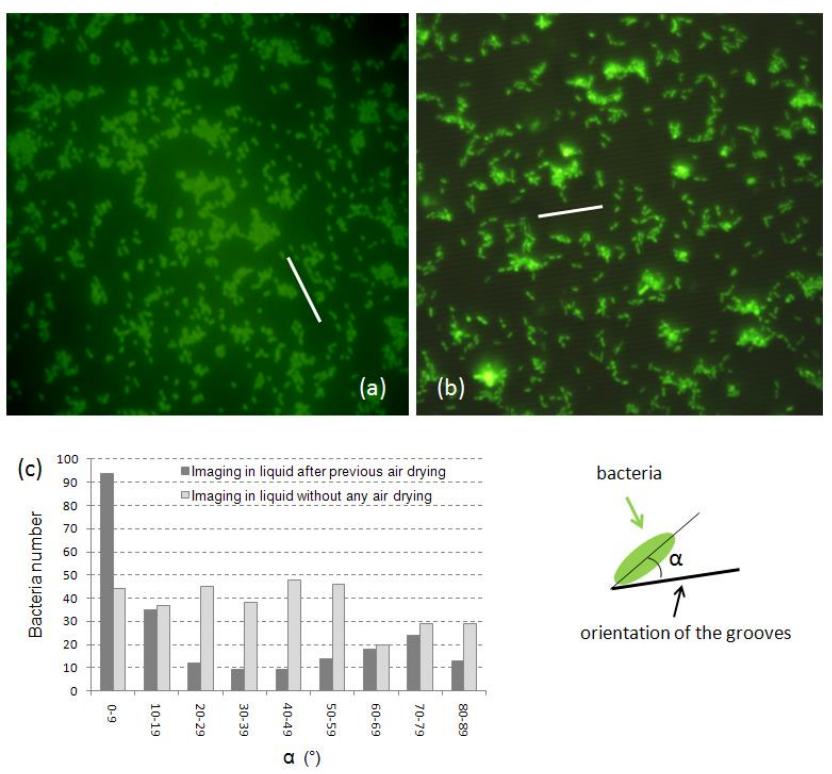

Figure 1: Adherent Escherichia coli K12 on microstructured substrates (see [8] for more details about the substrates) observed in immersion using epifluorescence microscope. (a) Substrates were kept in air during about $1 \mathrm{~h}$ before being immersed again in $\mathrm{NaCl}$ 9g/L solution. (b) Substrates were always kept immersed. (e) Orientation of the bacteria present on (a) and (b) micrographs in comparison with the grooves direction (indicated on the micrographs by the white bars).

\section{References}

[1] L. Ploux, S. Beckendorff, M. Nardin and S. Neunlist. Quantitative and morphological analysis of biofilm formation on self-assembled monolayers. Colloids Surfaces, B 2007; 57: 174-81.

[2] C. Díaz, R. C. Salvarezza, M. n. A. Fernández Lorenzo de Mele and P. L. Schilardi. Organization of Pseudomonas fluorescens on Chemically Different Nano/Microstructured Surfaces. ACS Applied Materials \& Interfaces 2010; doi: 10.1021/am100313z:

[3] G. Elender and E. Sackmann. Wetting and dewetting of $\mathrm{Si} / \mathrm{SiO} 2$-wafers by free and lipidmonolayer covered aqueous solutions under controlled humidity J. Phys. II 1994; 4: 455-79

[4] Y. Sun, V. Bromberg, S. Gawande and T. Singler. Effect of contact angle and humidity on evaporation of inkjet-printed colloidal drops. Bulletin of the American Physical Society - 62nd Annual Meeting of the APS Division of Fluid Dynamics 2009; 54:

[5] H. Celio, E. Barton and K. J. Stevenson. Patterned Assembly of Colloidal Particles by Confined Dewetting Lithography. Langmuir 2006; 22: 11426-35.

[6] Y. Sun and G. C. Walker. Two-Dimensional Self-Assembly of Latex Particles in Wetting Films on Patterned Polymer Surfaces. The Journal of Physical Chemistry B 2002; 106: 2217-23.

[7] K. Anselme, P. Davidson, A. M. Popa, M. Giazzon, M. Liley and L. Ploux. The interaction of cells and bacteria with surfaces structured at the nanometre scale. Acta Biomaterialia 2010; 6: 3824-46.

[8] L. Ploux, K. Anselme, A. Dirani, A. Ponche, O. Soppera and V. Roucoules. Opposite Responses of Cells and Bacteria to Micro/Nanopatterned Surfaces Prepared by Pulsed Plasma Polymerization and UV-Irradiation. Langmuir 2009; 25: 8161-9. 